\title{
KESULITAN-KESULITAN YANG DIHADAPI MAHASISWA PIAUD DALAM PEMBELAJARAN BAHASA INGGRIS
}

\author{
Nina Puspitaloka \\ Universitas Singaperbangsa Karawang \\ Email: nina.puspitaloka@fkip.unsika.ac.id \\ Yuna Tresna Wahyuna \\ Universitas Singaperbangsa Karawang \\ Email: yuna.tresna@yahoo.com
}

Article received: 09 Agustus 2018, Review process: 20 Agustus 2018

Article published: 30 September 2018

\begin{abstract}
This study aims to investigate English learning difficulties involved in PIAUD. The design of this study is qualitative. The results in this study indicate that the student's PIAUD S1 find difficulties in English learning. The difficulties are caused by factors and student's unpreparedness and also by the condition of students who still have very poor English skills, such as: lack of grammar, vocabulary, and pronunciation. From this research is expected to improve the ability in the process of handling the English language.
\end{abstract}

Keywords : Learning Difficulties, English, ESP.

\begin{abstract}
Abstrak
Penelitian ini bertujuan untuk melakukan investigasi terhadap kesulitan-kesulitan yang dihadapi mahasiswa PIAUD dalam pembelajaran Bahasa Inggris. Design yang digunakan adalah kualitatif. Hasil dalam penelitian ini menujukkan bahwa mahasiswa S1 prodi PIAUD menemukan kesulitan-kesulitan dalam belajar bahasa Inggris. Kesulitan tersebut disebabkan oleh faktor kompetensi dan ketidaksiapan mahasiswa serta disebabkan pula oleh kondisi mahasiswa yang masih memiliki kemampuan bahasa Inggris yang sangat kurang, seperti: kurangnya penguasaan grammar, kosa kata, dan pengucapan kata. Dari penelitian ini diharapkan agar mahasiswa dapat meningkatkan keterampilan dalam proses pembelajaran bahasa Inggris.
\end{abstract}

Kata Kunci : Kesulitan Belajar, Bahasa Inggris, ESP.

\section{PENDAHULUAN}

Bahasa Inggris merupakan bahasa penutur asing yang banyak digunakan di berbagai negara di dunia. Inggris sebagai bahasa pemersatu memiki peranan penting dalam komunikasi individu yang berasal dari negara berbeda dengan bahasa yang berbeda pula. 
Keterampilan memahami dan berkomunikasi dengan bahasa Inggris baik secara lisan maupun tulisan memberikan nilai tambah pada seseorang. Dengan demikian, banyak orang berlomba untuk belajar bahasa Inggris.

Dewasa ini, banyak instansi-instansi yang menawarkan program pembelajaran bahasa Inggris, tidak terkecuali dengan universitas-universitas negeri maupun swasta di Indonesia. Bahasa Inggris menjadi salah satu mata kuliah yang wajib diambil oleh mahasiswa baik yang berasal dari prodi bahasa Inggris maupun lainnya. Bahasa Inggris yang dipelajaripun kini mulai beragam disesuaikan dengan kebutuhan pebelajar dari bidang tertentu, seperti Bahasa Inggris untuk Matematika, Bahasa Inggris untuk Bisnis, Bahasa Inggris untuk Manajemen, dan lain sebagainya yang merupakan bagian dari English for Specific Purpose (ESP).

Hutchinson dan Waters (1987) dalam bukunya yang berjudul, "English for Specific Purpose: A Learning-Centered Approach" mendefinisikan bahwa ESP tidak hanya mengajar bahasa Inggris seperti pada umumnya, melainkan ada fitur-fitur kebahasaan yang tipikal dalam penggunaanya.

Berdasarkan penjelasan Hutchinson dan Waters, dapat disimpulkan bahwa English for Specific Purpose (ESP) merupakan pembelajaran bahasa Inggris yang diimplementasikan pada bidang yang lebih spesifik sehingga bahasa Inggris yang digunakan akan mengacu pada penggunaan bahasa yang sesuai dengan bidang yang dipilih. Misalnya, bila seseorang belajar bahasa Inggris untuk bidang ekonomi, maka ia akan mempelajari istilah-istilah Ekonomi dalam bahasa Inggris yang sesuai. Dengan demikian, salah penafsiran mengenai istilahistilah tertentu dalam bindang ekonomi dapat diminimalisir.

Sementara itu, Paltridge dan Starfield (2013), dalam bukunya yang berjudul, "The Handbook of English for Specific Purpose” mengemukakan bahwa ESP adalah pembelajaran bahasa Inggris sebagai bahasa dimana tujuan dari ESP learners ini adalah untuk menggunakan bahasa Inggris pada bidang tertentu. Selain itu, materi ESP juga disusun sesuai dengan pembelajaran bahasa Inggris yang memang dibutuhkan pebelajar.

Tidak jauh berbeda dengan penjelasan yang diberikan Hutchinson dan Waters mengenai ESP, Paltridge dan Starfield memberikan penjelasan mengenai ESP lebih kepada pemilihan pembelajaran bahasa Inggris yang harus disesuaikan dengan kebutuhan pebelajar bahasa Inggris dalam bidang tertentu. Dengan demikian, pembelajaran bahasa Inggris pada 
bidang tertentu tidak hanya menyajikan materi yang asal tanpa mempertimbangkan kebutuhan ESP Learners itu sendiri.

Sementara itu, McDough (1984) dalam bukunya yang berjudul, "ESP in Perspective" menjelaskan hasil observasinya terhadap beberapa tingkatan pada kelompok ESP learners mengenai beberapa karakteristik dari situasi belajar dan pembelajaran ESP. Menurutnya, diantara beberapa kelompok pebelajar, disana akan terdapat beberapa perbedaan seperti perbedaan dalam fase belajar, target bahasa yang telah diketahui, pengetahuan profesional, tipe subjek atau profesi, status, waktu yang tersedia untuk pembelajaran bahasa Inggris, motivasi dan ketertarikan, serta ekspektasi terhadap pembelajaran bahasa Inggris.

Berdasarkan pejelasan yang telah dipaparkan oleh McDough, dapat ditarik kesimpulan bahwa pada beberapa tingkatan pebelajar ESP, ada beberapa karakteristik berbeda yang ditunjukkan. Misalnya pada hal motivasi dan ketertarikan, guru, dosen, atau istruktur harus megetahui sejauh mana motivasi mereka untuk mengikuti kelas ESP. Dengan demikian dapat diperhitungkan bagaimana metode yang tepat dalam penyampaian materi ESP. Meskipun demikian, guru, dosen, atau istruktur tetap harus memperhatikan factor-faktor lain yang telah disebutkan.

Pembelajaran bahasa Inggris ini juga berlaku bagi mahasiswa S1 Program Studi Pendidikan Islam Anak Usia Dini di Universitas Singaperbagsa Karawang. Meskipun di tingkat perguruan tinggi, pembelajaran bahasa Inggris masih dianggap sulit oleh sebagian mahasiswa. Hal ini tentu akan mengakibatkan pembelajaran yang kurang maksimal. Hassan (dalam Fika: 2016) mengutarakan bahwa pebelajar bahasa Inggris mengalami kesulitan dalam memahami pengucapan bahasa Inggris yang didapatkan dalam materi menyimak (listening). Sementara pada keterampilan membaca, Rahmawati (dalam Fika: 2016) berpendapat bahwa pebelajar bahasa Inggris mengalami kesulitan dalam memahami ide satu kalimat dengan kalimat lainnya. Selain itu, dalam keterampilan menulis, pebelajar seringkali mengalami kesulitan dikarenakan dalam menulis membutuhkan pemikiran yang sistematis dan membutuhkan proses yang lama untuk menguasai keterampilan tersebut. Meskipun demikian, Rukmini (dalam Fika: 2016) mengungkapkan bahwa keterampilan menulis sangatlah penting karena pebelajar bahasa Inggris bisa mengungkapkan gagasan ataupun berkomunikasi lewat tulisan sehingga dapat dibaca oleh banyak orang. Sementara itu, dalam 
hal keterampilan berbicara, Megawati \& Mandarani (dalam Fika: 2016) dalam penelitiannya menemukan bahwa minimnya kosa kata bahasa Inggris yang dikuasai pebelajar bahasa Inggris menyebabkan mereka kesulitan untuk berkomunikasi dengan baik dan benar dalam bahasa Inggris.

Ada beberapa hal yang membuat mahasiswa merasa kesulitan dalam keterampilanketerampilan Bahasa Inggris. Misalnya, kesulitan yang kerapkali ditemui dalam keterampilan speaking (berbicara) biasanya dikarenakan karena penguasaan kosa kata yang kurang sehingga mahasiswa akan kesulitan untuk memulai percakapan dalam Bahasa Inggris. Selain itu, pengetahuan mereka yang kurang mengenai cara megucapkan kata dalam Bahasa Inggris juga sering membuat mereka ragu untuk berbicara dalam Bahasa Inggris. Terakhir, hal yang paling membuat mahasiswa merasa sulit untuk berbicara dalam Bahasa Inggris adalah pegetahuan mereka dalam grammar yang terbatas.

Sementara itu, dalam keterampilan listening (menyimak), mahasiswa merasa kesulitan untuk memahami ucapan yang mereka dengar dari native speaker (penutur bahasa asli). Hal ini juga disebabkan karena percakapan native speaker yang mereka anggap terlalu cepat. Sementara dalam memehami konten percakapan atau pembahasan, mereka merasa sulit dikarenakan kosa kata yang terbatas sehingga mereka sulit untuk mengartikan setiap kata yang keluar dari native speaker itu sendiri, ditambah mereka tidak punya waktu jika harus membuka kamus.

Lain halnya dalam keterampilan menulis (writing), mereka tidak terlalu menemukan kesulitan jika dibandingkan speaking dan listening. Hal ini dikarenakan ketika mereka diminta untuk menulis satu tulisan dalam Bahasa Inggris, biasanya mereka akan mendapatkan contoh atau gambaran sehingga mereka bisa mengikuti struktur tulisan yang telah dicontohkan. Selain itu, mereka juga bisa membuka kamus atau alat bantu lainnya untuk menerjemahkan dari bahasa Inggris ke bahasa Indonesia ataupun sebalikmya. Meskipun demikian, mahasiswa juga mengaku mengalami kesulitan menulis dalam bahasa Inggris. Kesulitan yang kerap kali mereka alami adalah dalam grammar. Seperti yang diketahui bahwa ketika menulis bahasa Inggris, maka tidak bisa dipisahkan dari kemampuan menulis dengan menggunakan tata bahasa (grammar) yang sesuai dengan yang telah 
ditentukan. Sementara pada elemen pronounciation dan vocabulary mereka tidak terlalu menghadapi kesulitan dalam keterampilan menulis bahasa Inggris.

Terakhir dalam keterampilan membaca (reading), mereka mengaku menghadapi lebih sedikit kesulitan jika dibandingkan dengan tiga keterampilan sebelumnya. Hal ini dikarenakan dalam keterampilan membaca, mereka hanya dituntut untuk memahami isi bacaan. Tidak seperti keterampilan yang lain, dalam keterampilan reading (membaca), mahasiswa tidak mesti mengetahui bagaimana pengucapan sebuah kata dalam bahasa Inggris. Mereka hanya dituntuk untuk mengutahi makna bacaan sehingga dapat diketahui maksud dari bacaan tersebut. Meskipun demikian, tidak dapat dipungkiri bahwa dalam keterampilan reading (membaca), mahasiswa juga kerap kali menghadapi kesulitan. Meskipun mereka dapat membuka kamus untuk mengertikan suatu kata dalam bahasa Inggris yang belum diketahui artinya, mereka tetap kesulitan memahami maksud teks secara keseluruhan. Hal ini disebabkan karena meskipun mereka telah mengartikan seluruh kata dalam bahasa Inggris yang tidak mereka pahami, pemahaman mereka terhadap suatu teks terkadang berlainan dengan maksud teks itu sendiri. Dengan demikian, mereka juga tetap menghadapi kesulitan dalam keterampilan membaca (reading).

Kesulitan-kesulitan yang dihadapi pebelajar bahasa Inggris ini tentunya akan memberikan dorongan kepada dosen bahasa Inggris agar memberikan perhatian lebih kepada peserta didik. Pendidik dapat mempersiapkan pembelajaran secara matang agar proses belajar bisa berjalan secara efektif. Persiapan dapat berupa pembuatan silabus dan Rencana Pembelajaran Semester (RPS), pemilihan materi dan media yang sesuai, serta cara penilaian yang baik dan benar. Dengan persiapan yang matang dan pengetahuan tentang kesulitankesulitan yang dihadapi peserta didik, dosen dapat meningkatkan kualitas pembelajaran agar peserta didik memiliki kemampuan yang diharapkan dalam bahasa Inggris.

Berdasarkan konsep-konsep yang telah dipaparkan, dapat diketahui bahwa banyak kesulitan-kesulitan yang dihadapi pebelajar bahasa Inggris. Dengan demikian, penulis tertarik untuk meneliti lebih dalam sejauh mana kesulitan-kesulitan yang dihadapi oleh mahasiswa pada pembelajaran bahasa Inggris, serta solusi dalam mengatasi kesulitankesulitan yang dihadapi khususnya pada pebelajar bahasa Inggris yang bukan dari jurusan bahasa Inggris atau yang umum disebut ESP Learners. 


\section{METODOLOGI}

Metode yang digunakan dalam penelitian ini adalah pendekatan kualitatif. Penelitian ini bertujuan untuk mengidentifikasi kesulitan-kesulitan (masalah-masalah) yang dihadapi oleh mahasiswa dalam mempelajari bahasa Inggris di Program Studi Pendidikan Islam Anak Usia Dini, Fakultas Agama Islam, Universitas Singaperbangsa Karawang.

Penelitian ini dilaksanakan pada semester genap Tahun Akademik 2017/2018. Subjek penelitian ini adalah mahasiswa semester II Program Studi Pendidikan Islam Anak Usia Dini di Universitas Singaperbangsa Karawang. Sebelumnya mahasiswa tersebut telah mendapatkan materi bahasa Inggris yang membahas tentang konsep dasar bahasa Inggris. Jumlah subjek dari penelitian ini adalah 48 Orang.

Instrumen yang digunakan dalam penelitian ini berupa lembar observasi, kuesioner, dan dokumentasi. Dengan demikian, pengumpulan data dilakukan dengan cara observasi, penyebaran kuesioner, dan dokumentasi. Observasi dilakukan selama kegiatan pembelajaran satu semester untuk mengamati mahasiswa yang tergolong aktif, kurang aktif, dan pasif. Mahasiswa dapat dikategorikan aktif ketika proses pembelajaran menunjukkan partisipasinya untuk menjawab pertanyaan, mengajukan pertanyaan, dan sering mengungkapkan pendapat saat kegiatan kelompok. Sedangkan untuk yang kurang aktif, dapat dilihat dari intensitas interaksi yang jarang terjalin antara mahasiswa tersebut dengan dosen. Mereka hanya aktif ketika diminta atau ditunjuk dosen untuk mengemukakan pendapatnya. Kategori yang terakhir yaitu pasif dimana mahasiswa hampir tidak pernah berkontribusi secara lisan dengan dosen, mendapatkan nilai ujian tengah semester yang rendah.

Teknik analisis data meliputi: data reduction, data display, dan conclusion drawing/ verification. Setelah semua data yang dibutuhkan terkumpul, peneliti melakukan reduksi data. Artinya peneliti merangkum, memilah hal-hal yang pokok atau data yang penting saja. Selanjutnya adalah penyajian data (data display). Penyajian data dalam penelitian kualitatif dilakukan dengan uraian, bagan, flowchart, dan sebagainya. Dalam hal penyajian data penelitian kualitatif, Miles dan Huberman (melalui Sugiyono, 2013 dalam Risatyah, 2015) menjelaskan bahwa teks naratif lebih sering digunakan. Langkah terakhir dalam analisis data penelitian ini adalah menarik simpulan (conclusion drawing/ verification). Simpulan dalam 
penelitian kualitatif mungkin berupa temuaan-temuan yang sudah dirumuskan sejak awal. Peneliti mungkin juga menemukan temuan baru yang memperkaya hasil penelitiannya.

\section{HASIL DAN PEMBAHASAN}

Dalam setiap proses pembelajaran, pelajar pasti pernah mengalami kesulitan-kesulitan dalam memahami materi yang disampaikan guru, dosen, atau instruktur. Kesulitan- kesulitan ini juga kerap kali ditemukan pada pelajar, dalam hal ini adalah mahasiswa, saat pembelajaraan bahasa Inggris. Tidak dapat dipungkiri bahwa Inggris sebagai bahasa asing menjadi salah satu mata kuliah yang sering diaggap sulit oleh mahasiswa, terlebih bagi mahasiswa yang berasal dari luar program studi Pendidikan Bahasa Inggris. Berikut ini akan dipaparkan hasil penelitian yang dilakukan pada mahasiswa program studi Pendidikan Islam Anak Usia Dini (PIAUD), Fakultas Agama Islam (FAI), Universitas Singaperbangsa Karawang (UNSIKA) mengenai kesulitan-kesulitan yang mereka hadapi saat pembelajaran bahasa Inggris.

Berdasarkan hasil yang diperoleh dari angket, setiap mahasiswa memiliki pendapat yang beragam mengenai kesulitan-kesulitan yang dihadapi ketika belajar bahasa Inggris. Dari hasil pengolahan data berupa kuesioner menunjukkan bahwa keterampilan speaking (berbicara) menempati posisi pertama dalam keterampilan bahasa paling sulit. Hal ini disebabkan karena kurangnya penguasaan kosa kata bahasa Inggris, adanya perbedaan antara pengucapan dan penulisan bahasa Inggris sehingga mereka merasa bingung untuk berbicara dalam bahasa Inggris, serta pemahaman yang sangat minim dalam grammar (tata bahasa). Alasan lain yang meyebabkan keterampilan berbicara (speaking) menjadi keterampilan bahasa paling sulit adalah adanya rasa kurang percaya diri pada mahasiswa dikarenakan bahasa Inggris jarang bahkan tidak pernah dipraktekkan dalam kehidupan sehari-hari. Sementara itu, berdasarkan hasil observasi, mahasiswa prodi PIAUD, FAI, UNSIKA banyak mengalami kesulitan dalam hal pengucapan (pronunciation). Hal ini disebabkan karena adanya perbedaan antara penulisan dan pengucapan.

Dalam keterampilan berbicara (speaking), peneliti mengadopsi cara penilaian dari Student Oral Language Observation matrix oleh Daniel \& Bizar (2004). Daniel dan Bizar (dalam Nunan 2005) berpendapat bahwa keterampilan speaking dapat dinilai berdasarkan beberapa elemen berbahasa, seperti: grammar (tata bahasa), vocabulary (kosa kata), 
pronunciation (pengucapan), fluency (kelancaran), volume (tinggi rendah suara), dan confidence (kepercayaan diri). Pada masing-masing elemen, Daniel dan Bizar membagi kemampuan dalam beberapa kategori dari tingkat terendah sampai tertinggi. Pada elemen grammar (tata bahasa), seseorang akan mendapat poin tertinggi dalam keterampilan berbicara (speaking) apabila selalu meggunakan tata bahasa yang tepat, tanpa adanya kesalahan. Sebaliknya, seseorang akan mendapat poin paling rendah apabila terdapat banyak sekali error dalam struktur bahasa (grammar) yang diucapkan. Sementara itu, pada elemen kosa kata (vocabulary), seseorang akan mendapat poin tertinggi apabila kosa kata yang digunakan sangatlah luas. Artinya, orang tersebut memiliki pemahaman mengenai penggunaan kosa kata yang sangat beragam sehingga dapat menggunakan kosa kata dengan tepat. Sebaliknya, seseorang akan mendapat poin terendah dalam elemen kosa kata, apabila penggunaan kosa kata orang yang bersangkutan sangatlah terbatas. Untuk elemen pengucapan (pronunciation), seseorang akan mendapatkan poin tertinggi apabila ia bisa bisa mengucapkan setiap kata dengan jelas sehingga mudah dimengerti. Sebaliknya, seseorang akan mendapatkan poin terendah dalam elemen ini apabila ia tidak bisa mengucapkan setiap kata dengan tepat, seperti kesalahan dalam penekanan (stress) yang mana penekanan dalam bahasa Inggris ini akan sangat berpengeruh terhadap arti. Sementara itu, untuk elemen kelancaran (fluency), seseorang akan mendapatkan poin tertinggi, apabila seseorang berbicara dengan sangat mulus tanpa adanya hambatan. Sebaliknya, seseorang akan mendapatkan poin terendah apabila pembicaraannya putus-putus dan banyak sekali hambatan. Pada elemen volume (tinggi rendahnya suara), seseorang akan mendapatkan poin tertinggi apabila ia dapat berbicara dengan suara yang jelas dan cukup tinggi sehingga dapat terdengar oleh seluruh audience dalam suatu presentasi. Sebaliknya, ia akan mendapat poin terendah apabila suara yang dihasilkan terlalu kecil sehingga tidak dapat terdengar dengan jelas oleh pendengar apa yang hendak disampaikan. Pada elemen terakhir, yakni kepercayaan diri (confidence), seseorang akan mendappatkan poin tertinggi, apabila bahasa tubuh yang ditunjukkan sangat menyakinkan, seperti berdiri dengan tegak dan percaya diri, kontak mata yang meyakinkan, dll. Sebaliknya, seseorang akan mendapat poin paling rendah, apabila ia menunjukkan bahasa tubuh yang tidak meyakinkan, seperti posisi berdiri yang tidak tegak, tidak adanya kontak mata, dsb. 
Berdasarkan hasil pengamatan pada responden yang merupakan mahasiswa prodi PIAUD, FAI, UNSIKA, ditemukan bahwa sebagian besar mahasiswa mengalami kesulitan pada semua elemen berbahasa saat berbicara dalam bahasa Inggris. Sebagian besar mahasiswa mendapat poin yang rendah pada elemen terkait, karena setiap elemen akan mempengaruhi elemen yang lain. Peneliti menemukan bahwa saat berbicara dalam bahasa Inggris, pengucapan yang dihasilkan sangatlah kurang. Selain itu, tata bahasa (grammar) yang digunakan pun banyak mengalami kesalahan. Penguasaan kosa kata (vocabulary) yang terbatas pun membuat kelancaran mereka dalam berbicara bahasa Inggris pun terhambat sehingga mereka kurang percaya diri dalam berbicara bahasa Inggris.

Keterampilan bahasa Inggris paling sulit, yang menempati posisi kedua, berdasarkan hasil pengolahan data berupa kuesioner adalah listening (mendengarkan). Hal ini dikarenakan saat mendengar audio dalam bahasa Inggris, mahasiswa merasa kesulitan dalam megikuti kecepatan berbicara native speaker (penutur bahasa asli). Selain itu, minimnya penguasaan kosa kata bahasa Inggris juga menjadi faktor yang membuat mahasiswa kesulitan dalam memahami isi percakapan dalam bahasa Inggris. Alasan lain yang diutarakan mahasiswa merasa kesulitan dalam keterampilan listening (mendengarkan) disebabkan karena adanya perbedaan aksen bahasa Inggris dari negara-negara yang memakai bahasa Inggris sebagai bahasa pertama.

Ummah, S (2012) berpendapat bahwa keterampilan menyimak (listening) adalah salah satu dari empat keterampilan bahasa Inggris yang cukup sulit karena mahasiswa dituntut untuk memahami bahasa yang diucapkan oleh penutur asli (native speaker) secara verbal (spoken English). Hal ini sejalan dengan penemuan yang ditemukan pada mahasiswa PIAUD, FAI, UNSIKA dimana mereka pun menghadapi kesulitan-kesulitan saat pembelajaran bahasa Inggris terutama pada keterampilan menyimak (listening). Mereka mengaku merasa kesulitan untuk memahami apa yang dikatakan native speker (penutur bahasa asli) dalam audio dikarenakan apa yang native speaker ucapkan terlalu cepat. Selain itu, mereka juga tidak terbiasa mendengar dan mempraktekkan percakapan bahasa Inggris dalam kehidupan seharihari.

Seperti yang diketahui bahwa soal dalam keterampilan listening tidak hanya menuntut mahasiswa untuk memahami apa isi perkacapan, tetapi juga terkadang berhubungan dengan 
soal TOEFL. Dengan kesulitan yang mereka hadapi saat mendengarkan ucapan native speaker yang menurut pendengaran mereka terlalu cepat, ditambah dengan soal TOEFL yang sulit, menyebabkan listening menjadi salah satu keterampilan yang dianggap sangat sulit.

Sementara itu, berdasarkan hasil kuesioner yang telah diisi responden, writing (menulis) menjadi keterampilan bahasa Inggris paling sulit yang menempati posisi ketiga. Kebanyakan mahasiswa berpendapat bahwa keterampilan menulis tidak terlalu sulit jika dibandingkan dengan speaking dan listening. Meskipun begitu, kebanyakan mahasiswa tidak memungkiri bahwa keterampilan menulis memiliki kesulitan tersendiri, seperti adanya proses yang harus mereka lewati saat mulai menulis dalam bahasa Inggris, dibutuhkan kekreatifan dalam mencurahkan ide menulis, serta adanya aturan-aturan baku dalam kepenulisan, khususnya untuk kepenulisan ilmiah. Sementara itu, untuk menilai hasil tulisan mahasiswa PIAUD, FAI, UNSIKA, peneliti mengadopsi Jacobs et.al. 's Scoring Profile. Jacob, dkk dalam Weigle (2002: 10) memberikan skala analisis dalam menilai keterampilan menulis atau tulisan seseorang dapat dilihat dari isi (content), organisasi (organization), kosa kata (vocabulary), tata bahasa (grammatical), serta mekanik (mechanic).

Jacobs dkk melalui Weigle dalam Puspitaloka (2014: 75) memberikan penilaian pada keterampilan menulis dalam bahasa Inggris dari nilai terendah sampai tertinggi berdasarkan beberapa kriteria. Untuk nilai tertinggi sampai terendah dapat diuraikan dalam beberapa kategori, yakni excellent to very good, good to average, fair to poor, dan very poor. Jika dilihat dari isi (content) tulisan, seseorang akan mendapat kategori excellent to very good apabila memiliki kriteria seperti berisi pengetahuan luas, subtantif, dikembangkan berdasarkan thesis, dan sesuai dengan topik yang ditugaskan. Sementara itu, tulisan seseorang akan masuk dalam kategori good to average apabila isi (content) tulisannya memiliki kriteria seperti berisi pengetahuan yang cukup luas mengenai subjek yang dibahas, pengembangan thesis yang terbatas, berkaitan dengan topik yang dibahas meskipun kurang mendetail. Sementara itu, tulisan seseorang akan masuk dalam kategori fair to poor apabila isi (content) tulisannya memiliki kriteria seperti berisi pengetahuan yang terbatas tentang subjek yang dibahas, pengembangan topiknya tidak memadai, dan sedikit bahasan mengenai topik. Sementara itu, seseorang akan masuk dalam kategori very poor apabila tulisannya memiliki kriteria seperti 
tidak dapat menunjukkan pengetahuan tentang subjek yang dibahas, tidak substantive, tidak bersangkutan dengan topik yang dibahas, dan tidak cukup untuk dievaluasi.

Setelah membahas mengenai isi (content) tulisan, maka hal yang masih berkaitan dengan kepenulisan adalah organisasi/struktur tulisan (organization). Dalam hal organisasi tulisan, seseorang akan masuk dalam kategori excellent to very good apabila tulisannya memiliki kriteria seperti ide yang disebutkan dengan jelas, kohesif, diorganisasikan dengan baik, urutannya logis, dsb. Sementara itu, seseorang akan masuk dalam kategori good to average apabila tulisannya memiliki kriteria seperti organisasi tulisan yang cukup baik, main idea yang disebutkan cukup jelas meskipun terkadang ada tulisan yang kurang mulus, kalimat pendukungnya terbatas, logis tetapi urutannya tidak lengkap. Selain itu, tulisan seseorang akan termasuk pada kategori fair to poor apabila organisasi tulisannya memiliki kriteria seperti kesalahan yang sering terjadi pada pilihan atau penggunaan kata/bentuk idiom, dan memiliki makna yang membingungkan. disamping itu, tulisan seseorang termasuk kategori very poor apabila tulisannya memiliki kriteria seperti tulisan yang tidak terorganisasi dengan baik, tidak komunikatif, dan tidak dapat dinilai.

Selanjutnya, dalam penggunaan kosa kata, seseorang akan termasuk kategori excellent to very good apabila kosa kata yang digunakan dalam tulisannya memiliki kriteria seperti ide yang disebutkan dengan jelas, kohesif, diorganisasikan dengan baik, urutannya logis, dsb. Sementara itu, seseorang akan masuk dalam kategori good to average apabila tulisannya memiliki kriteria seperti organisasi tulisan yang cukup baik, main idea yang disebutkan cukup jelas meskipun terkadang ada tulisan yang kurang mulus, kalimat pendukungnya terbatas, logis tetapi urutannya tidak lengkap. Selain itu, tulisan seseorang akan termasuk pada kategori fair to poor apabila organisasi tulisannya memiliki kriteria seperti kesalahan yang sering terjadi pada pilihan atau penggunaan kata/bentuk idiom, dan memiliki makna yang membingungkan. Disamping itu, tulisan seseorang termasuk kategori very poor apabila tulisannya memiliki kriteria seperti tulisan yang tidak terorganisasi dengan baik, tidak komunikatif, dan tidak dapat dinilai. Dengan demikian, penilaian dalam hal organisasi dan kosa kata memiliki kriteria yang identik.

Setelah peniliaian berdasarkan penggunaan kosa kata, maka hal yang dilihat lainnya adalah penilaian tulisan berdasarkan grammatical (struktur bahasa). Tulisan seseorang akan 
masuk kedalam kategori excellent to very good apabila tulisannya menggunakan kalimat kompleks yang efektif, tidak adanya kesalahan dalam grammar, tidak adanya kesalahan dalan penggunaan tenses, tidak adanya kesalahan dalam penggunaan articles (contoh: $a$, an, the), tidak adanya kesalahan dalam penggunaan pronouns (kata ganti), preposition, dsb. Sementara itu, tulisan seseorang akan termasuk dalam kategori good to average apabila tulisannya memiliki kriteria seperti menggunakan kalimat efektif namun sederhana, sedikit kesalahan dalam penggunaan kalimat kompleks, dan terdapat beberapa kesalahan dalam grammar, seperti sedikit kesalahan dalan penggunaan tenses, sedikit kesalahan dalam penggunaan articles (contoh: $a$, an, the), sedikit kesalahan dalam penggunaan pronouns (kata ganti), preposition, dsb. Selain itu, tulisan seseorang akan termasuk pada kategori fair to poor apabila tulisannya memiliki kriteria seperti banyaknya kesalahan dalam penggunaan kalimat sederhana maupun kompleks, kesalahan yang sering terjadi pada grammar, seperti kesalahan yang sering terjadi dalam penggunaan tenses, kesalahan yang sering terjadi dalam penggunaan articles (contoh: $a$, an, the), kesalahan yang sering terjadi dalam penggunaan pronouns (kata ganti), preposition, dsb. Disamping itu, tulisan seseorang akan termasuk dalam kategori very poor apabila tulisannya memiliki kriteria yang tidak dapat dinilai karena banyaknya kesalahan dalam struktur bahasa.

Terakhir, dalam keterampilan menulis (writing), tulisan seseorang akan diamati pada penggunaan tanda baca, ejaan atau dalam bahasa Inggris dikenal dengan istilah mechanics. Dalam mekanisme tulisan ini, tulisan seseorang akan masuk dalam kategori excellent to very good apabila tulisannya memiliki kriteria seperti penggunaan tanda baca dan ejaan yang baik dan benar, paragrafnya terstruktur dengan baik, serta pengunaan huruf kapital pada kata yang seharusnya. Sementara itu, tulisan seseorang akan termasuk pada kategori good to average apabila tulisannya memuat kriteria seperti sedikit kesalahan pada penggunaan tanda baca dan ejaan. Selanjutnya, tulisan seseorang akan termasuk dalam kategori fair to poor apabila tulisannya memiliki kriteria seperti banyaknya kesalahan dalam penggunaan tanda baca dan penulisan ejaan, makna pada tulisannya membingungkan, serta struktur paragraph yang kurang rapi. Terakhir, yang paling rendah, tulisan seseorang akan masuk dalam kategori very poor apabila tulisannya memiliki kriteria seperti didominasi oleh kesalahan pada penggunaan tanda 
baca dan penulisan ejaan, kesalahan dalam penempatan huruf kapital sehingga tulisannya tidak akan pernah cukup untuk dievaluasi.

Setelah dipaparkan mengenai kategori dan kriteria penilaian keterampilan menulis (writing), dapat ditarik kesimpulan bahwa setelah peneliti melakukan observasi pada mahasiswa S-1 prodi PIAUD, FAI, UNSIKA ditemukan bahwa sebagian besar mahasiswa mengalami kesulitan dalam menulis menggunakan bahasa Inggris. Hal ini dapat dilihat dari hasil tulisan sebagian besar mahasiswa yang kebanyakan masuk pada kategori fair to poor pada setiap bidang penilaian seperti pada isi (content), organisasi tulisan (organization), kosa kata (vocabulary), tata bahasa (grammatical), dan mekanisme tulisan (mechanics).

Adapun keterampilan bahasa Inggris paling sulit yang menempati posisi terendah adalah reading. Kebanyakan mahasiswa berpendapat bahwa keterampilan membaca tidak terlalu sulit dikarenakan mereka bisa membuka kamus untuk mencari tahu arti dari kosa kata yang belum dipahami. Meskipun demikian, mahasiswa tidak memungkiri adanya kesulitan dalam keterampilan membaca ini. Kesulitan yang kerap kali mereka hadapi adalah memahami ide dari suatu bacaan. Hal ini juga disebabkan karena kurangnya kosa kata bahasa Inggris yang dipahami, serta kurangnya kemampuan menangkap pesan dari suatu bacaan.

Menurut Kustanti (2016) dalam jurnalnya yang berjudul, "Kesulitan Dan Solusi Pembelajaran English Reading Text” berpendapat bahwa:“Tujuan membaca adalah salah satu aspek penting dalam membaca yang sering diabaikan dalam membaca efektif. Akibatnya, banyak pembaca, terutama pembaca bahasa Inggris, yang cenderung menyamaratakan strategi mereka untuk semua jenis membaca. Tidak jarang seorang pembelajar yang sebenarnya hanya perlu mendapatkan gagasan utama suatu bacaan "terjebak" dalam pergulatan dengan kata-kata sukar yang muncul dalam bacaannya. Tidak sedikit pula yang berpendapat bahwa membaca, untuk tujuan apa pun, memerlukan pemahaman yang tepat tentang arti setiap kata dalam teks. Dampak buruknya jelas: tujuan membaca gagal tercapai, atau kalaupun tercapai, tidak dengan cara yang efisien. Coben (1990), misalnya, berpendapat bahwa tujuan membaca yang sudah jelas pada awal membaca akan membantu pembaca memutuskan apakah perlu melakukan skimming, atau scanning, atau membaca secara responsif, membaca untuk hiburan, dan sebagainya. Schmitt (1990) membagi kegiatan membaca menjadi tiga: sebelum membaca, selama membaca, dan setelah membaca. Pada fase awal disarankan agar membuat serangkaian 
pertanyaan tentang topik yang akan dicari jawabannya pada fase selama membaca. Fase setelah membaca digunakan untuk mengetahui apakah pertanyaanpertanyaan yang diajukan pada fase sebelum membaca sudah bisa terjawab dengan baik. Cara ini sangat bermanfaat bagi pelajar atau mahasiswa yang sedang berusaha memperkaya pengetahuannya tentang teori-teori tertentu dari buku teks atau artikel ilmiah yang lainnya. Kembali pada penggunaan strategi secara hirarkis, skimming dan scaning dapat dioperasikan secara berurutan. Dimulai dengan menetapkan tujuan membaca. Umumnya, tujuan membaca adalah menemukan beberapa informasi dari teks. Setiap pengajar bahasa haruslah menyadari serta memahami benar-benar bahwa membaca adalah suatu keterampilan yang kompleks, yang rumit, yang mencakup atau melibatkan serangkaian keterampilan-keterampilan yang lebih kecil. Kesulitan-Kesulitan yang dialami peserta didik dapat diatasi dengan memperhatikan faktor-faktor yang mempengaruhinya. Kesulitan dalam Pronounciation. Vocabulary building, meaning, translation, topic paragraph akan mudah diatasi dengan pembelajaran yang tepat sehingga dapat membantu dalam belajar reading".

Berdasarkan hasil yang telah dipaparkan, dapat disimpulkan bahwa kesulitankesulitan yang dihadapi mahasiswa PIAUD UNSIKA dalam pembelajaran bahasa Inggris secara garis besar dipengaruhi oleh tingkat penguasaan mahasiswa dalam keterampilan bahasa seperti speaking, listening, writing, reading dan komponen bahasa seperti vocabulary, grammar, dan pronunciation. Hal ini dapat dilihat dari pendapat mahasiswa yang menyatakan bahwa speaking adalah keterampilan bahasa paling sulit. Adapun faktor yang mempengaruhi kesulitan-kesulitan ini adalah dikarenakan kurangnya kosa kata bahasa Inggris yang mereka kuasai, minimnya pemahaman mengenai struktur bahasa Inggris yang baik dan benar, dan kurangnya praktek penggunaan bahasa Inggris dalam kehidupan sehari-hari.

Melihat kenyataan ini, solusi-solusi yang tepat sangat dibutuhkan dalam mengatasi kesulitan-kesulitan yang dihadapi mahasiswa dalam pembelajaran bahasa Inggris. Kebanyakan mahasiswa berpendapat bahwa pembelajaran bahasa Inggris sebaiknya diberikan dengan cara yang efektif dan menyenangkan sehingga tujuan dari pembelajaran dapat dicapai. Untuk keterampilan speaking, misalnya, dosen, pendidik, dan atau instruktur 
dapat menggunakan metode bermain peran, dimana mahasiswa dapat secara aktif terlibat dalam proses pembelajaran serta dapat mempraktekkan bahasa Inggris secara langsung.

Pemilihan materi yang sesuai dengan kebutuhan mahasiswa juga sangat dianjurkan. Hal ini dikarenakan materi yang sesuai dengan bidang yang mereka tekuni akan meningkatkan minat belajar bahasa Inggris dalam diri mereka. Pemilihan materi yang sesuai ini berkaitan dengan English for Spesific Purpose yang telah dibahas dalam pendahuluan. Dalam hal ini, dosen, guru, dan atau instruktur dapat menyusun silabus pembelajaran, dimana materi yang akan disampaikan harus sesuai dengan bidang yang tengah mereka tempuh. Dengan demikian, kesulitan-kesulitan yang dihadapi dapat diminimalisir sehingga proses pembelajaran bahasa Inggris dapat berjala secara efektif dan minim hambatan.

\section{SIMPULAN}

Dalam pembelajaran bahasa Inggris, mahasiwa seringkali dihadapkan dengan kesulitan-kesulitan yang menyebabkan tidak tercapainya tujuan pembelajaran itu sendiri. Kesulitan-kesulitan tersebut dapat dilihat dari berbagai keterampilan bahasa ataupun komponen bahasa yang dipelajari. Setelah peneliti melakukan penelitian mengenai kesulitan-kesulitan yang dihadapi mahasiswa program studi Pendidikan Anak Usia Dini, Fakultas Agama Islam, Universitas Singaperbangsa Karawang, penelitian dapat menarik kesimpulan yang akan dipaparkan sebagai berikut.

Dalam penelitian ini ditemukan bahwa urutan keterampilan bahasa yang paling sulit hingga mudah adalah sebagai berikut Speaking (berbicara), Listening (menyimak), Writing (menulis), dan terakhir Reading (membaca). Berbicara (speaking) menjadi keterampilan yang dianggap paling sulit karena sebagian besar mahasiswa memiliki kosa kata yang terbatas dalam bahasa Inggris sehingga menghambat mereka untuk berbicara dalam bahasa Inggris. Selain itu, pengucapan dalam bahasa Inggris yang berbeda dengan tulisan menjadi kesulitan tersendiri yang dihadapi mahasiswa pada keterampilan berbicara (speaking). Terakhir, kesulitan yang dihadapi mahasiswa pada keterampilan berbicara (speaking) ini adalah berkaitan dengan elemen tata bahasa (grammar). Mereka kerap kali merasa kesulitan untuk berbicara dalam bahasa Inggris dikarenakan terhambat oleh kemampuan grammar mereka yang masih sangat minim. 
Sementara itu, pada keterampilan menyimak (listening), mahasiswa menghadapi kesulitan dalam memahami apa yang dikatakan oleh native speaker (penutur bahasa asli) dikarenakan mereka berpendapat bahwa apa yang diucapkan native speaker itu terlalu cepat. Kurangnya kosa kata yang dikuasai juga menjadikan mereka kesulitan untuk menyimak percakapan dalam bahasa Inggris. Dengam demikian, menyimak (listening) menjadi keterampilan tersulit yang menempati posisi kedua setelah keterampilan berbicara (speaking).

Selanjutnya, pada keterampilan menulis (writing), mahasiswa berpendapat bahwa mereka tidak terlalu menghadapi kesulitan jika dibandingkan dengan keterampilan berbicara (speaking) dan menyimak (listening). Meskipun demikian, tidak dapat dipungkiri bahwa dalam keterampilan menulis (writing), mereka tetap menghadapi kesulitan. Mereka berpendapat bahwa pada keterampilan ini, mereka dituntut untuk menguasai tata bahasa (grammar). Sementara, seperti yang telah dikatahui, pemahaman mereka terhadap grammar masih sangat minim. Dengan demikian, menulis (writing) menjadi keterampilan bahasa Inggris tersulit yang menempati urutan ketiga.

Terakhir, dalam keterampilan membaca (reading), mahasiswa tidak terlalu mengalami kesulitan jika dibandingkan tiga keterampilan lainnya yakni berbicara (speaking), menyimak (listening), dan menulis (writing). Meskipun demikian, tidak dapat dipungkiri bahwa keterampilan membaca (reading) memiliki kesulitan tersendiri. Salah satu kesulitan yang mereka hadapi adalah tatkala membaca teks berbahasa Inggris kemudian diminta untuk menjawab pertanyaan, mereka terkadang mengalami kesulitan. Misalnya, ketika diminta untuk menyebutkan ide dalam suatu teks, mereka mengaku masih kebingungan. Meskipun mereka bisa membuka kamus untuk mencari arti dari kata yang belum mereka pahami, mereka tetap kesulitan untuk memahami seluruh bacaan dalam bahasa Inggris. Dengan demikian, membaca (reading) menjadi keterampilan bahasa Inggris tersulit yang menempati urutan terakhir berdasarkan kuesioner yang disebarkan pada mahasiswa program studi Pendidikan Islam Anak Usia Dini, Fakultas Agama Islam, Universitas Singaperbangsa Karawang.

Faktor yang menyebabkan kesulitan-kesulitan tersebut adalah kurangnya penguasaan vocabulary yang merupakan salah satu dari komponen-komponen berbahasa, minimnya 
pemahaman mengenai struktur bahasa Inggris yang baik dan benar, serta kurangnya praktek berbahasa Inggris dalam kehidupan sehari-hari, juga beberapa penyebab lain yang teletak pada faktor afektif siswa. Dengan demikian, untuk meminimalisir kesulitankesulitan yang dihadapi mahasiswa PIAUD UNSIKA dalam pembelajaran bahasa Inggris, dosen dapat mengimplementasikan metode yang efektif selama proses pembelajaran serta memilih materi yang sesuai dengan kebutuhan mahasiswa.

\section{DAFTAR PUSTAKA}

Hutchinson, T. \& Alan Waters (1987). English for Specific Purpose: A Learning-Centered Approach. New York: Cambridge University Press.

Jhon, dkk. (2009). Developments in English for Specific Purpose: A-Muli-disciplinary Approach. Cambridge: Cambridge University Press.

Jordon, R.R. (2009). English for Academic Purpose: A guide and Resume Book for Teacher. Cambridge: Cambridge University Press.

Kustanti, Dewi. (2016). Kesulitan Dan Solusi Pembelajaran English Reading Text. Jurnal al-Tsaqafa, 13(1).

Master, Peter. (1998). Responses to English for Specific Purposes. California: San Jose State University.

McDonough, Jo. (1984). ESP in Perspectives. London: Collins ELT.

Megawati, Fika. (2016). Kesulitan Mahasiswa dalam Mencapai Pembelajaran Bahasa Inggris Secara Efektif. Jurnal Pedagogia, 5(2).

Paltridge, B and Sue Starfield. (2013). The Handbook of English for Specific Purpose. Chichester: Jhon Wiley \& Sons, Inc.

Puspitaloka, Nina. (2014). The Effects of Grammar Mastery and Critical Thinking Towards Students' Descriptive Writing Skill.

Risatyah, Anisa (2015). Analisis Kebutuhan Pembelajaran Bahasa Inggris S1 Agroteknologi Fakultas Pertanian UNSIKA.

Suyadi \& Ulfah, M. 2013. Konsep Dasar PAUD. Bandung: PT Remaja Rosdakarya.

Ummah, S.S. (2012). Problematika dalam Belajar Listening Comprehension yang Dihadapi Oleh Mahasiswa Semester III Tadris Bahasa Inggris STAIN Pamekasan. Jurnal Nuansa, 9(1) 